\title{
ANNALS
}

OF

\section{The Entomological Society of America}

Volume VII SEPTEMBER, 1914 Number 3

\section{SPIDERS COLLECTED BY MR. C. WILLIAM BEEBE IN BURMA AND BORNEO. With Plate XXVI.}

Alexander Petrunkevitch, PH. D.

Family Theraphosidre.

Haplopelma Dorix (Thorell). One female from Kuching, Borneo. Family Drassida.

Drassodes Drydeni n. sp. One male from Pongatong, Burma.

Drassodes ignobilis $\mathrm{n}$. $\mathrm{sp}$. One female from Tabu Pum, Burma.

Family Pholcidx.

Pholcus phalangioides Fussl. One female from Wahsaung, Burma. Family Theridiidæ.

Theridion sarapus Thorell. Two females from Pongatong, Burma.

Dipoena tristis n. sp. One female from Tabu Pum, Burma.

Enoplognatha marmorata L. One immature female from Tabu Pum, Burma.

Family Linyphiidæ.

Erigone longipalpus F. Two males and two females from Tabu Pum, Burma.

Linyphia sp? One immature female from Tabu Pum, Burma:

Family Clubionidze.

Clubiona tabupumensis n. sp. One female from Tabu Pum, Burma.

Clubiona sp? One young from Tabu Pum, Burma.

Clubiona sp? Two young from Wahsaung, Burma.

Palystes sp? One young from Wahsaung, Burma. 
Family Argiopidæ.

Nephila maculata F. One female from Wahsaung, Burma.

Nephila clavata L. Koch. Two females from Tabu Pum, Burma.

Leucauge tesselata (Thorell). One female from Pongatong, Burma.

Gasteracantha arcuata F. One female from Kuching, Borneo.

Gasteracantha frontata B1. Two females from Kuching, Borneo.

Theridiosoma sp? One young from Tabu Pum, Burma.

Araneus microtuberculatus n. sp. One female from Tabu Pum, Burma.

Araneus Beebei n. sp. One female from Wahsaung, Burma.

Family Thomisidæ.

Philodromus tabupumensis n. sp. One female from Tabu Pum, Burma.

Bomis $\mathrm{sp}$ ? One young without abdomen, from Wahsaung, Burma.

Porrhopis sp? One young from Wahsaung, Burma.

Family Lycosidæ.

Lycosa stictopyga Thorell. One female from Tabu Pum, Burma.

Lycosa (Pirata) sp? One immature female from Tabu Pum, Burma.

Lycosa sp? One young from Tabu Pum, Burma.

Family Oxyopidæ.

Oxyopes sp? One young from Wahsaung, Burma.

Oxyopes sp? Two young from Wahsaung, Burma.

Family Salticidre.

Evophris sp? One young from Wahsaung, Burma.

Evophris albopatella n, sp. One male from Wahsaung, Burma.

Cobanus Beebei n. sp. One male from Central Borneo.

Ballus tabupumensis n. sp. One female from Tabu Pun, Burma.

Attulus sp? One young from Wahsaung, Burma.

Thiania sp? One young from Wahsaung, Burma.

Description of new species.

Drassodes Drydeni* n. sp. (Plate XXVI, figs. 1 and 2).

Total length $7.4 \mathrm{~mm}$. Cephalothorax and all appendages brown, abdomen grey. Sternum oval, pointed behind, broadly truncated in front. Lip much longer than wide. Laminæe maxillares strongly impressed. All femora slightly thickened. Cephalothorax much narrower in front than in middle. Anterior row of eyes recurved, posterior procurved. AME half their diameter apart, subcontiguous with ASE. Eyes of second row aequidistant. ASE separated from PSE by less than half their diameter. AME slightly larger than ASE. Anterior row viewed from in front curved downward. Clypeus as high as AME. First tarsus and metatarsus with a heavy scopula. Second tarsus with a scopula only in its distal half. Second metatarsus without scopula.

* In honor of Mr. John Dryden Kuser. 
Heavy spines on all legs. Femur of pedipalp with a short blunt subterminal apophysis on the inside. (Plate XXVI, fig. 2). Copulatory apparatus with an extremely long and thin embolus (Plate XXVI, fig. 1).

\section{One male from Pongatong, Burma.}

\section{Drassodes ignobilis n. sp. (Plate XXVI, fig. 3).}

Total length $5.9 \mathrm{~mm}$. Cephalothorax and all appendages brown, abdomen dark grey. All femora slightly thickened. Tarsi without scopulæ. Sternum oval, broadly truncated in front, pointed behind. Lip longer than wide. Laminæe maxillares strongly impressed. Fourth legs with spines. All femora with two long, upright spines in median dorsal line. No spines on other joints of first, second and third leg. Anterior row of eyes recurved, posterior row procurved. PME about their diameter apart. PSE about half diameter from PME. Eyes of anterior row equal in size, contiguous. Anterior row viewed from in front curved downward. Side eyes scparated by about half their diameter. Clypeus as high as AME. Epigynum as figured, much higher than wide.

\section{One female from Tabu Pum, Burma.}

\section{Dipoena tristis n. sp. (Plate XXVI, fig. 4).}

Total length $4.8 \mathrm{~mm}$. Cephalothorax and legs reddish brown, Abdomen dark greyish brown with a narrow dark median line and two pairs of transverse whitish bands. No spines on legs. Sternum triangular. Anterior coxæ widely apart. Lip wider than long. Anterior row of eyes strongly recurved, posterior row straight, longer than . anterior. Eyes of posterior row aequidistant and equal in size. Side eyes contiguous, equal. AME smaller than the other eyes. Eyes of anterior row acquidistant. Clypeus as high as quadrangle. Epigynum as figured.

\section{One female from Tabu Pum, Burma.}

\section{Clubiona tabupumensis n. sp. (Plate XXVI, fig. 5).}

Total length $7.8 \mathrm{~mm}$. Cephalothorax and all appendages yellowish brown, abdomen grey. Anterior row of eyes much shorter than posterior row, slightly recurved. Posterior row almost straight. Quadrangle wider than long, much narrower in front than behind. Eyes of anterior row aequidistant, separated from each other by somewhat less than their diameter. PME somewhat farther from each other than from the PSE. Distance between the PME equal to about 21/2 their diameter. Clypeus not more than half the diameter of the AME. Sternum a long oval, pointed behind, truncated in front. Lip much longer than wide. First and second tarsi and metatarsi with a thick scopula. Similar scoptula on distal half of third and fourth tarsi. First tibia with 2-2 long spines below, first metatarsi with 2 long spines at base below. Third and fourth tibia with a row of 3 spines in median line below, 2 laterals inside 
and 2 laterals outside. Third and fourth metatarsi with spines below, above and laterals. Epigynum very small, considerably in advance of genital slit.

One female from Tabu Pum, Burma.

Araneus microtuberculatus n. sp. (Plate XXVI, figs. 6, 7, 8).

Total length $2.8 \mathrm{~mm}$. Cephalothorax high, without groove or stria. Abdomen with two tubercles or shoulders in front and two prominent tubercles behind. (Plate XXVI, figs. 7, 8). Integuments soft. Side eyes subcontiguous, on black tubercles. ASE much smaller than PSE. Both rows of eyes recurved. Quadrangle wider behind than in front, wider than long. PME much larger than AME. Clypeus lower than quadrangle, about twice the diameter of the AME. Sternum triangular, broadly truncated in front. It is also truncated behind, between the hind coxæ which in consequence are separate. Lip triangular, very wide. Chelæ smooth, inferior margin with 3 teeth, superior with 4 teeth. Pedipalpi with a claw. One dorsal spine at end of all patellas. One inside lateral spine on first femur and tibia. Upper claws almost cordate, with four teeth each. Third claw smooth. Epigynum as figured. (Plate XXVI, fig. 6). Color in alcohol: cephalothorax brown with a median white spot. Chele brown, legs brown, femora lighter than other joints. Sternum dark brown, lip and laminæ with tips of lighter color. Abdomen above mottled with whitc and brown, tubercles dark. Sides whitish with three dark lines. Below almost black. Spinnerets brown.

One female from Tabu Pum, Burma.

Araneus Beebei n. sp. (Plate XXVI, figs. 9, 10).

Total length $2.5 \mathrm{~mm}$. Cephalothorax with a somewhat recurved groove. Clypeus not half the diameter of the AME. Quadrangle much wider in front than behind. Anterior row strongly recurved, posterior row slightly recurved. AME are the largest eyes. Chelæe distinctly longer than thick. Inferior margin with 3 teeth, superior margin with 4 teeth. Abdomen oval, considerably overlapping cephalothorax. Sternum triangular, widely truncated in front, produced behind between the fourth coxæ which are separate. Pedipalpi with a claw. Legs with many spines. Two rows of long bristles below all femora, especially on those of the first and second pair. Epigynum as figured, brown and relatively very large. (Plate XXVI, fig. 9). Color in alcohol : cephalothorax greyish brown, legs yellow, sternum, lip, laminæ, pedipalpi and chelæ also yellow. Abdomen (Plate XXVI, fig. 10) above grey with white iridescent spots, a transverse anterior black band and a large median more or less triangular black spot pointed backwards. Below grey with iridescent white spots.

\section{One female from Wahsaung, Burma.}


Philodromus tabupumensis n. sp. (Plate XXVI, fig. 11).

Total length $4.8 \mathrm{~mm}$. Cephalothorax $1.8 \mathrm{~mm}$. long, $2.0 \mathrm{~mm}$. wide. Legs 2134. Anterior row of eyes shorter than the posterior row and recurved. Posterior row very slightly recurved, almost straight. Anterior cyes about equal in size, AME farther from each other then from the ASE. PME smaller than the PSE, the distance between the PME much larier than between the PME and the PSE. Quadrangle narrower in front than behind, about as wide as long. Clypeus 11/2 diameters of the AME. Sternum longer than wide, emarginate between hind coxa which are widely separate. Spines on all segments of legs and palpi, except tarsi. First femur $2.2 \mathrm{~mm}$. long, second $2.6 \mathrm{~mm}$. Color in alcohol: cephalothorax light brown with black marginal and three black longitudinal parallel bands. A narrow, curved black band runs in front of the eycgroup, touches the PSE on cach side of the head and merges with the median longitudinal band at the posterior margin of the cephalothorax. Legs yellow, spotted above with dark brown. Abdomen above light brown with two dark brown V-shaped spots pointed forward, sides dark brown, underside altogether light yellow. Epigynum as figured.

\section{One female from Tabu Pum, Burma.}

\section{Evophris albopatella n. sp. (Plate XXVI, figs. 12, 13).}

Total length $2.7 \mathrm{~mm}$. Legs 4312 . Inferior margin of chela with one tooth, superior with a row of eight teeth. Of these only the proximal two are large, while the others are exceedingly small. (Plate XXVI, fig. 12). Cephalic part shorter than thoracic. Eyegroup wider in front than behind. ASE very prominent. Eyes of second row minute, situated in middle. Iridescent white scales above AME, between side eyes on face and along the edge of the cephalothorax which is very dark brown. First, second and third femur, patella and tibia dark brown above and below. Fourth femur yellow with a dark brown spot above at distal end. Fourth patella and tibia yellow above with two lateral dark brown lines, below yellow. All other joints of all legs yellow. Palpi dark brown except patella which is covered with white iridescent scales. Sternum, lip and lamina dark brown with yellow edges. Chelæ reddish brown. Abdomen above yellow with two parallel longitudinal dark brown bands and white iridescent scales. Below yellow with a median dark brown broad band. Tibia of pedipalp with a curved apophysis, copulatory apparatus as figured. (Plate XXVI, fig. 13).

One male from Wahsaung, Burma.

Cobanus Beebei n. sp. (Plate XXVI, figs. 14-18).

Total length without mandibles $9.0 \mathrm{~mm}$. Cephalothorax $3.8 \mathrm{~mm}$. long, $3.1 \mathrm{~mm}$. wide. Chelr long, with long, curved fang. Length of chelic without fang $3.8 \mathrm{~mm}$. Superior margin with two teeth of 
which the subapical one considerably larger than the proximal. Inferior margin with two teeth. (Plate XXVI, fig. 14). Legs 3142. Cephalothorax high. Eyes of second row small, situated behind the middle. Measurements of legs: First leg-femur $4.6 \mathrm{~mm}$., tibia + patella $5.5 \mathrm{~mm}$. metatarsus + tarsus $4.8 \mathrm{~mm}$.; Second leg-femur $3.3 \mathrm{~mm}$., tibia + patella $3.5 \mathrm{~mm}$., metatarsus + tarsus $3.6 \mathrm{~mm}$.; Third leg-femur $5.2 \mathrm{~mm}$., tibia+ patella $5.1 \mathrm{~mm}$., metatarsus + tarsus $5.8 \mathrm{~mm}$.; Fourth leg-femur 3.0 $\mathrm{mm}$., tibia + patella $3.7 \mathrm{~mm}$., metatarsus + tarsus $4.5 \mathrm{~mm}$. All legs with many heavy spines. Tibia of first leg curved, with 4-4 spines below. First metatarsi straight, with 2-2 long spines below and laterals. A heavy comb of black hair above and below first patella, a comb of shorter hair on distal half of femur and one of quite short hair on back of first tibia (Plate XXVI, fig. 15). Claws as figured (Plate XXVI, fig. 17). Sternum longer than wide, lip not reaching half of lamina. (Plate XXVI, fig. 16). Tibia of pedipalp with a straight apophysis, copulatory apparatus as figured (Plate XXVI, fig. 18). Color in alcohol: cephalothorax red-brown, with two lateral white patches and a fringe of brown hair around the eyes. Chelæ above red-brown, below black. Fang black with red-brown tip. Pedipalpi yellow. First femur and patella very dark brown, tibia yellow with dark brown distal ond, metatarsus and tarsus dark brown. Other legs brown, fourth leg lighter. Lip and laminæ dark brown, sternum reddish brown. Abdomen dark grey above and below.

\section{One male from Central Borneo.}

Ballus tabupumensis n. sp. (Plate XXVI, figs. 19, 20).

Total length $5.7 \mathrm{~mm}$. Legs 1423. Cephalothorax flat and square. Eyegroup wider behind than in front. Pars cephalica longer than pars thoracica. Eyes of second row minute, situated considerably in front of middle. Posterior row somewhat shorter than width of cephalothorax. Chelæ short and heavy (Plate XXVI, fig. 20) with a humped back carrying a row of tubercles. Inferior margin with three teeth of which the middle one is the smallest. Superior margin with a row of 12 very small teeth. Sternum much longer than wide, posterior coxæ contiguous. Lip longer than broad, laminæ very long with emarginate outer edge, wider at end than at base, inclined over lip. First leg much heavier than the others. First femora dilated. First tibia with $3-3$ heavy spines below and no laterals. First metatarsus with $2-2$ very heavy spines below, the first pair reaching beyond the middle of the article and the second pair almost to the base of the claws, no laterals. Claws with a single tooth. Epigynum as figured (Plate XXVI, fig. 19). Color in alcohol: cephalothorax, chelæ and first leg very dark brown. Abdomen and femora of second, third and fourth pair brown. Other joints of second, third and fourth leg yellow with dark spots. Underside dark brown.

\section{One female from Tabu Pum, Burma.}


Explanation of Plate XXVI.

Drassodes Drydeni n. sp.-male.

Fig. 1. Copulatory apparatus of male.

Fig. 2. Femoral apophysis of pedipalp.

Drassude's ignolitis n. sp.-female.

Fig. 3. Epigynum.

Dipoena tristis n. sp.-female.

Fig. 1. Epigynum.

Clubiona tabupumensis n. sp.-female.

Fig. 5. Epigynum.

Araneus microtuberculatus n. sp.-female,

Fig. 6. Epigynum.

Fig. 7. Sideview of abdomen and cephalothorax.

Fig. 8. Dorsal view of abdomen.

Araneus Beebei n. sp.-female.

Fig. 9. Epigynum.

Fig. 10. Dorsal view of abdomen.

Philodromus tabupumensis n. sp.-female.

Fig. 11. Epigynum.

Evophrys albopatella n. sp.-male.

Fig. 12. Chela.

Fig. 13. Copulatory apparatus.

Cobanus Becbei n. sp.-male.

Fig. 14. Chela.

Fig. 15. First leg.

Fig. 16. Sternum, lip and laminæ.

Fig. 17. Claws.

Fig. 18. Copulatory apparatus.

Ballus tabupumensis n. sp.-female.

Fig. 19. Epigynum.

Fig. 20. Chelæ. 

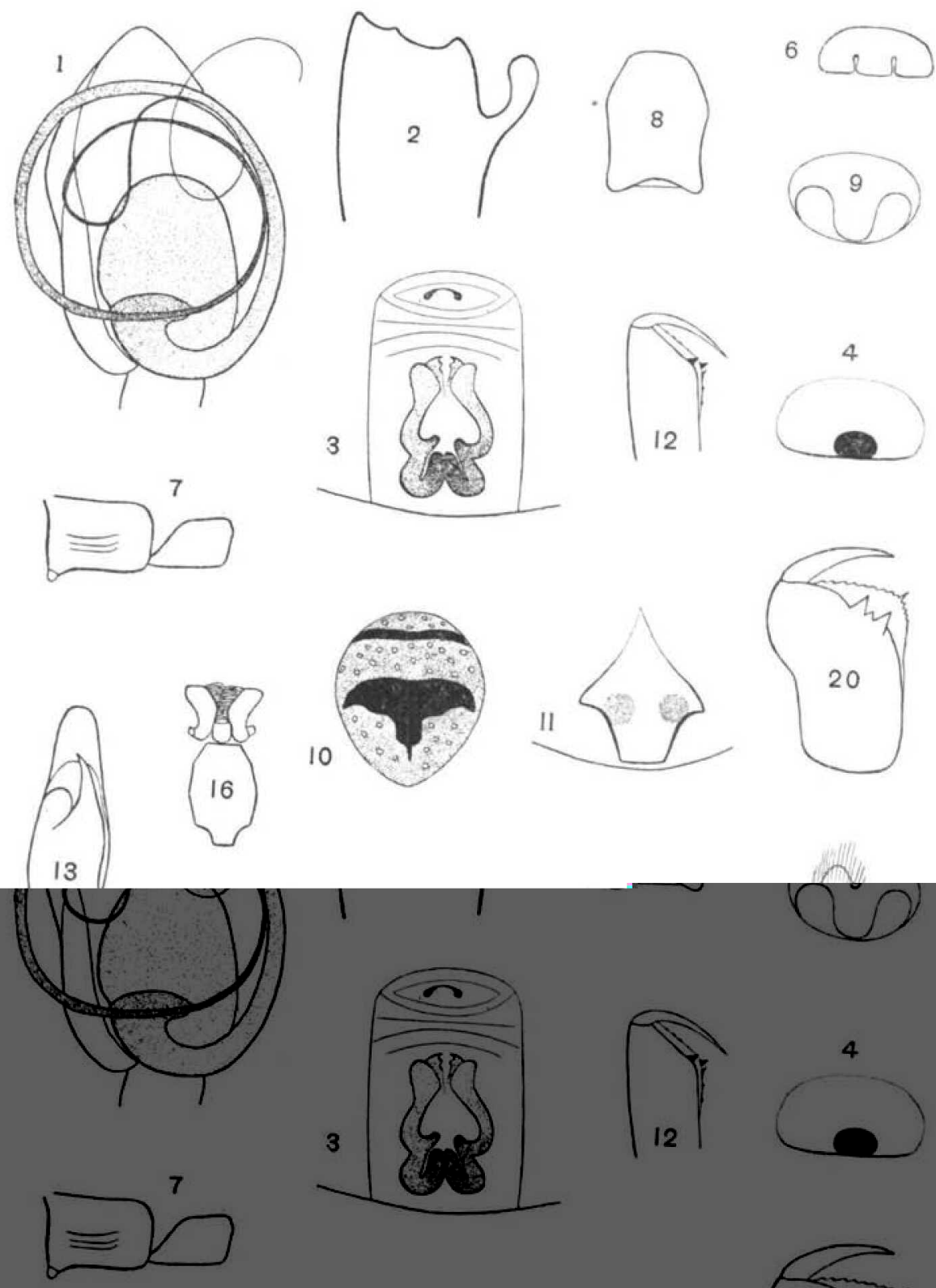

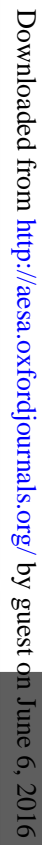
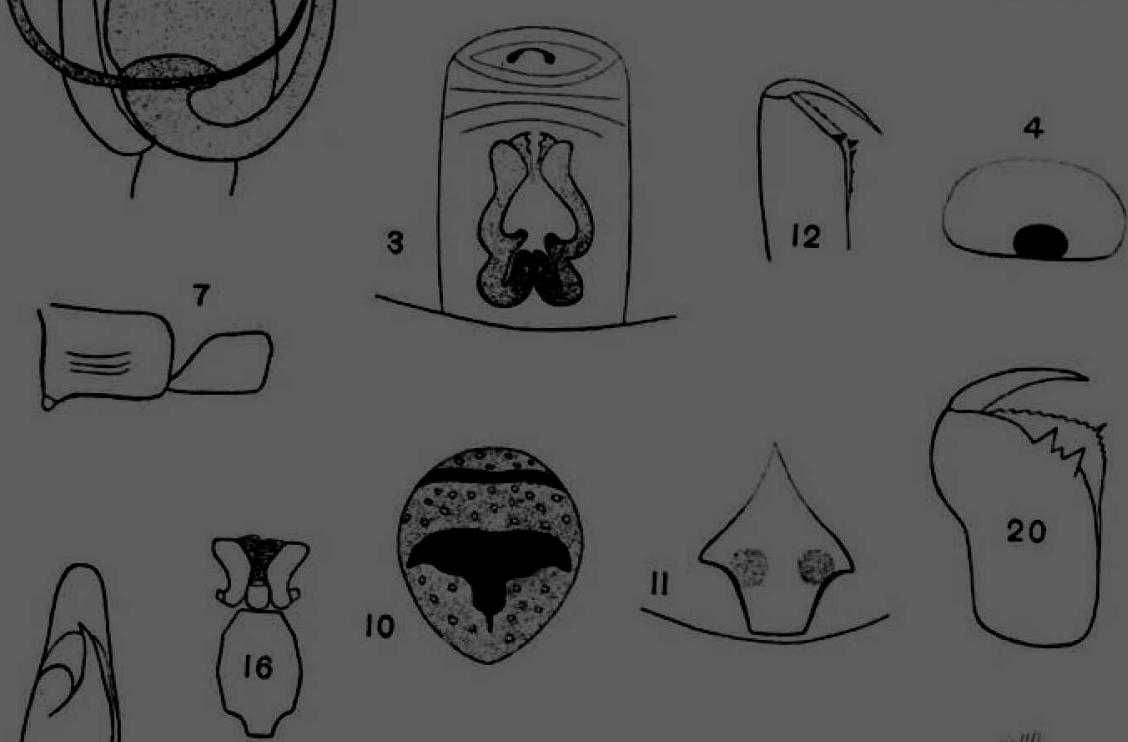